\title{
HUBUNGAN ANTARA KOMPETENSI GURU DENGAN MOTIVASI BELAJAR PADA SISWA BOARDING SCHOOL SMP PLUS AL-AQSHA
}

\author{
Siti Homisati Solihah, Ulfiah \& Ening Ningsih \\ Fakultas Psikologi UIN Sunan Gunung Djati Bandung, Jl. A.H Nasution No. 105 Bandung \\ email: neng.yayang@facebook.com
}

\begin{abstract}
Abstrak
Kompetensi mengajar guru merupakan kemampuan yang dimiliki guru dalam kaitanya dengan pelaksanaan kegiatan belajar mengajar di kelas. Kemampuan yang dimiliki guru tersebut diduga membuat siswa menaruh rasa kagum, hormat, mudah mencerna materi, serta semangat mengikuti proses belajar, sehingga secara tidak langsung motivasi belajarnya diharapkan meningkat. Secara konseptual, yang dimaksud kompetensi guru dalam penelitian adalah kemampuan seorang guru dalam melaksanakan kewajiban-kewajibannya secara bertanggungjawab dan layak (Barlow 1985). Sedangkan motivasi belajar dalam penelitian ini mengandung arti keseluruhan daya penggerak psikis di dalam diri siswa yang menimbulkan kegiatan belajar, menjamin kelangsungan kegiatan belajar dan memberikan arah pada kegiatan belajar itu demi mencapai suatu tujuan (Winkel, 2009). Penelitian ini dilakukan dengan menggunakan desain penelitian korelasional dan diuji dengan menggunakan rumus Rank Spearman. Subjek yang akan diteliti adalah seluruh siswa kelas IX di SMP Plus Al-Aqsha yang berjumlah 130 orang, yang secara otomatis akan menjadi populasi target. Berdasarkan hasil perhitungan dapat diketahui bahwa nilai probabilitas sebesar 0,001 lebih kecil dari $\alpha=0,05$. Hal tersebut memiliki arti bahwa H0 dalam penelitian ini ditolak, artinya terdapat hubungan positif antara kompetensi guru dengan motivasi belajar.
\end{abstract}

Kata kunci : Kemampuan, motivasi belajar, sekolah berasrama

\begin{abstract}
Teacher competences is a capability in doing teaching learning process in the class. That competences expected making the students respect to the teacher, enjoy the learning process and increase their motivation. According to Barloe (1985) teacher competences are teacher capability in doing their work and responsilibity. Meanwhile, learning motivation is students psychological effort that encourage learning activity and give direction on learning to get a certain goal (Winkel, 2009). This research used correlational design and Rank Spearman formula. Subject are 130 grade IX Junior High School students. Probability value is 0,001 which is less than $\alpha=0,05$. It means that Ho is rejected and it is concluded that there is positive correlation between teacher competences and learning motivation.
\end{abstract}

Keywords : competences, learning motivation, boarding school

\section{PENDAHULUAN}

Pendidikan dengan berbagai programnya mempunyai peranan penting dalam proses memperoleh dan meningkatkan kualitas kemampuan professional individu. Melalui pendidikan, seseorang dipersiapkan untuk memiliki bekal agar siap tahu, mengenal, dan mengembangkan metode berpikir secara sistema- 
tik agar dapat memecahkan masalah yang akan dihadapi dalam kehidupan di kemudian hari.

Pengertian pendidikan telah banyak diutarakan dan menurut Undang-Undang Republik Indonesia No 20 Tahun 2003 tentang Pendidikan Nasional :

"Pendidikan adalah usaha sadar dan terencana untuk mewujudkan suasana belajar dan proses pembelajaran agar peserta didik secara aktif mengembangkan potensi dirinya untuk memiliki kekuatan spiritual keagamaan, pengendalian diri, kepribadian kecerdasan, akhlak mulia, serta keterampilan yang diperlukan dirinya, masyarakat, bangsa dan Negara."

Dengan memperhatikan pengertian pendidikan seperti yang diutarakan tersebut maka dapat dikatakan bahwa peran pendidikan adalah sebagai landasan untuk membentuk, mempersiapkan, membina dan mengembangkan kemampuan sumber daya manusia yang sangat menentukan dalam keberhasilan pembangunan ke depan.

Pendidikan merupakan upaya untuk meningkatkan kemampuan dan kecerdasan manusia guna mempersiapkan masa depannya. Dalam pendekatannya, pendidikan adalah alat yang esensial dan pondasi yang mendasar bagi pembangunan manusia sebagai sumber daya dalam melahirkan manusia berkualitas. Pendidikan merupakan salah satu upaya untuk mengembangkan sumber daya manusia, terutama untuk mengembangkan aspek kemampuan intelektual dan kepribadian manusia yang perlu dilakukan secara terus-menerus.

Kebutuhan penyesuaian diri remaja terhadap guru merupakan tugas lain yang harus dilaksanakan remaja setelah dia dapat dengan baik menyesuaikan diri dengan kelompok teman sebaya. Kebutuhan penyesuaian diri remaja dengan guru timbul karena remaja ingin "melepaskan diri" keterikatan dari orang tua ingin mendapatkan orang dewasa lain yang dapat dijadikan "sahabat" dan pembimbing.

Bagi remaja berhubungan dengan guru sangat penting, karena dengan keakraban hubungan mereka dapat bergaul secara harmonis dan matang. Terjadinya kerawanan hubungan guru dengan remaja disebabkan kedua belah pihak tidak dapat menyesuaikan diri masingmasing. Ketidakmampuan remaja menyesuaikan diri dan ketidak-berdayaan remaja untuk mendapatkan sesuatu keuntungan lebih banyak dari para guru, membuat remaja kecewa, karena remaja tidak dapat merealisasikan doro- ngan-dorongannya untuk menunjukkan kedewasaan bergaul dengan orang-orang dewasa. Penolakan orang dewasa itu dapat menimbulkan perasaan rendah diri, yang lebih lanjut dapat mengganggu kestabilan pribadi remaja tersebut.

Meski kemampuanya untuk beradaptasi dengan guru dan teman sebaya harus dilakukan oleh remaja, tetapi mereka juga tidak bisa mengabaikan tugas mereka untuk menyeseuaikan diri terhadap bahan pelajaran baru dalam mata pelajaran yang telah di terima sebelumnya atau belum pernah diterima sama sekali. Penyesuaian diri di sini berhubungan dengan masalah kesiapan remaja untuk menerima bahan pelajaran dengan segenap jiwa raga.

Sebagai tenaga professional yang sangat menentukan jatuh bangunnya suatu bangsa dan negara, guru seharusnya menyadari bahwa tugas mereka sangat berat, bukan hanya sekedar menerima gaji setiap bulan. Dengan kesadaran itu diharapkan terlahir motivasi atau meningkatkan kompetensi self study.

Guru menpunyai peran penting dalam mencapai tujuan pembelajaran. Untuk mencapai tujuan pembelajaran tersebut, guru menampilkan perilaku-perilaku yang menunjang pembelajaran di kelas. Perilaku yang ditampilkan guru dalam mengajar merupakan manifestasi dari kemampuan yang dimilikinya sebagai seorang guru. Kemampuan-kemampuan yang dimiliki seorang guru dalam menjalankan tugasnya merupakan ciri-ciri dari kompetensi guru. Guru yang mengarahkan kegiatan belajar para siswanya, guru juga merupakan faktor penentu dalam keberhasilan proses belajar. Oleh karena itu guru harus mempunyai prinsip-prinsip belajar disamping menguasai materi disamping menguasai materi yang diajarkan. Dengan kata lain, guru harus mampu menciptakan suatu situasi belajar dengan sebaik-baiknya.

Dalam menjalankan tugasnya sebagai pendidik, seorang guru dituntut untuk mempunyai kompetensi yang berhubungan dengan perannya sebagai pengajar. Kompetensi adalah seperangkat pengetahuan, keterampilan dan prilaku yang harus dimiliki, dihayati dan dikuasai oleh guru dalam melaksanakan tugas keprofesionalan (Martinis Yamin 2006).

Kompetensi merupakan satu kesatuan yang utuh yang menggambarkan potensi, pengetahuan, keterampilan, dan sikap yang dinilai, yang terkait dengan profesi tertentu berkenaan dengan bagian-bagian yang dapat diak- 
tualisasikan dan diwujudkan dalam bentuk tindakan atau kinerja untuk menjalankan profesi tertentu. Kompetensi menjadi syarat mutlak menuju profesionalitas. Kompetensi merupakan hakikat kualitatif dari perilaku seseorang.

Pengertian dasar kompetensi (competency) adalah kemampuan atau kecakapan. Di samping berarti kemampuan, kompetensi juga berarti keadaan berwewenang atau memenuhi syarat menurut ketentuan hukum (McLeod, 1989).

Menurut Lefrancois (dalam Jamal Ma'mur, 2009: 37) kompetensi merupakan kapasitas untuk melakukan sesuatu yang dihasilkan dari proses belajar. Selama proses belajar, stimulus akan bergabung dengan isi memori dan menyebabkan terjadinya perubahan kapasitas untuk melakukan sesuatu. Apabila individu sukses dalam mempelajari cara melakukan satu pekerjaan yang kompleks dari sebelumnya, maka dari diri individu tersebut pasti sudah terjadi perubahan kompetensi. perubahan kompetensi tidak akan tampak apabila selanjutnya tidak ada kepentingan atau kesempatan untuk melakukan.

Kompetensi dikategorikan mulai dari tingkat sederhana atau dasar hingga lebih sulit atau kompleks yang pada gilirannya akan berhubungan dengan proses penyusunan bahan atau pengalaman belajar, yang lazimnya terdiri dari penguasaan minimal kompetensi dasar, praktik kompetensi dasar, serta penambahan, penyempurnaan, atau pengembangan terhadap kompetensi atau keterampilan. Ketiga kompetensi tersebut dapat terus berlanjut selama masih ada kesempatan untuk melakukan penyempurnaan atau pengembangan kompetensi.

Adapun kompetensi guru menurut Barlow (1985) merupakan kemampuan seorang guru dalam melaksanakan kewajiban-kewajibannya secara bertanggungjawab dan layak. Jadi, kompetensi profesionalisme guru dapat diartikan sebagai kemampuan dan kewenangan guru dalam menjalankan profesi keguruannya. Artinya, guru yang piawai dalam melaksanakan profesinya dapat disebut sebagai guru yang kompeten dan professional.

Sukiat (1992) menyatakan bahwa guru dan siswa merupakan suatu tim kerja, tidak bisa berdiri sendiri. Oleh karena itu, guru dan siswa harus dapat saling berkerja sama dalam hal kegiatan belajar mengajar di dalam kelas, guru juga diharapkan memiliki kompetensi atau memenuhi syarat menurut ketentuan hu- kum. Guru wajib memiliki kualifikasi akademik, kompetensi, sertifikat pendidik, sehat jasmani dan rohani, serta memiliki kemampuan untuk mewujudkan tujuan pendidikan nasional. Adapun kompetensi guru menurut Undang-undang Republik Indonesia No 14 Tahun 2005 tentang guru terdiri dari:

Kompetensi Pedagogis. Kompetensi utama yang harus dimiliki guru agar pembelajaran yang dilakukan efektif dan dinamis adalah kompetensi pedagogis. Guru harus belajar secara maksimal untuk menguasai kompetensi pedagogis ini secara teori dan praktik. dari sinilah, perubahan dan kemajuan akan terjadi dengan pesat dan produktif. Kompetensi Pedagogis dalam standar nasional pendidikan, penjelasan pasal 28 ayat 3 butir (a) dikemukakan bahwa kompetensi pedagogis merupakan kemampuan guru dalam pengelolaan pembelajaran peserta didik yang sekurang-kurangnya meliputi hal-hal sebagai berikut: pemahaman wawasan atau landasan kependidikan, pemahaman terhadap peserta didik, pengembangan kurikulum/silabus, perancangan pembalajaran, pelaksanaan pembelajaran yang mendidik dan dialogis, pemanfaatan teknologi pembelajaran, evaluasi proses dan hasil belajar, pengembangan peserta didik untuk mengaktualisasikan berbagi potensi yang dimilikinya.

Kompetensi pedagogis mempunyai 10 indikator sebagai berikut: a). Menguasai karakteristik peserta didik dari aspek fisik, moral, spiritual, sosial, kultural, emosional, dan intelektual. b). Menguasai teori belajar dan prinsip-prinsip pembelajaran yang mendidik. c). Mengembangkan kurikulum yang terkait dengan mata pelajaran. d). Menyelenggrarakan pembelajaran yang mendidik dan dialogis. e). Memanfaatkan teknologi informasi dan komunikasi. f). Memfasilitasi pengembangan potensi peserta didik. g). Berkomunikasi secara efektif, empatik, dan santun. h). Menyelenggarakan penilaian dan evaluasi proses dan hasil belajar. i). Memanfaatkan hasil penilaian dan evaluasi. j). Melakukan tindakan reflektif untuk peningkatan kualitas pembelajaran.

Kompetensi Kepribadian. Seorang guru dinilai tidak hanya dari aspek keilmuan saja, tapi juga dari aspek kepribadian yang ditampilkannya. Kepribadian menunjuk pada organisasi sikap-sikap seseorang untuk berbuat, mengetahui, berpikir dan merasakan secara khusus apabila dia berhubungan dengan orang lain atau menanggapi suatu keadaan. seorang guru harus mempunyai kepribadian sehat yang akan 
mendorongnya mencapai puncak prestasi. Kepribadian yang sehat dapat diartikan kepribadian yang secara fisik dan psikis terbebas dari penyakit tetapi juga diartikan sebagi individu yang secra psikis selalu berusaha menjadi sehat. Kompetensi kepribadian sekurang-kurangngnya mencakup: berakhlak mulia, arif dan bijaksana, mantap, berwibawa, stabil, dewasa, jujur, mampu menjadi telasan bagi peserta didik dan masyarakat, secara objektif mengevalusi kinerja sendiri, mengembangkan diri secara mansiri dan berkelanjutan.

Disinilah, seorang guru dituntut untuk mempunyai kepribadian menarik agar mampu membangkitkan semangat belajar anak didik dan menanamkan mentalitas pemenang. Beberapa indikator kepribadian baik yang optimis dan progresif adalah: bertanggung jawab, tidak emosional, lemah lembut, tegas, tidak menakut-nakuti, serta dekat dengan anak didik.

Kompetensi Sosial. Sikap dan perilaku guru menjadi cermin masyarakat. maka, dalam kehidupan sehari-hari, guru harus mempunyai kompetensi sosial. Guru tidak sekedar manusia biasa, tapi sosok manusia yang mempunyai idealisme tinggi dalam melakukan perubahan di tengah masyarakat ke arah yang lebih baik dan lebih dinamis.

Kompetensi sosial dalam kegiatan belajar ini berkaitan erat dengan kemampuan guru dalam berkomunikasi dengan masyarakat di sekitar sekolah dan masyarakat tempat guru tinggal sehingga peranan dan cara guru berkomunikasi dengan masyarakat diharapkan memiliki karakteristik tersendiri yang sedikit banyak berbeda dengan orang lain yang bukan guru.

Kompetensi sosial merupakan kemampuan guru sebagai bagian dari masyarakat, sekurang-kurangnya meliputi kemampuan: a) Berkomunikasi lisan, tulisan, dan atau isyarat, b) Menggunakan teknologi komunikasi dan informasi secara fungsional, c) Bergaul secara efektif dengan peserta didik, sesama pendidik, tenaga kependidikan, pimpinan satuan pendidikan, orang tua/wali peserta dididk, d) Bergaul secara santun dengan masyarakat sekitar dengan mengindahkan norma serta sistem nilai yang berlaku, e) Menerapkan prinsip-prinsip persaudaraan dan semangat kebersamaan.

Kompetensi Profesional. Kompetensi profesional merupakan kemampuan guru dalam menguasai pengetahuan bidang ilmu teknologi dan seni yang sekurang-kurangnya me- liputi penguassaan: a) Materi pelajaran secara luas dan mendalam sesuai standar isi program satuan pendidikan, mata pelajaran, dan kelompok mata pelajaran yang dilampauinya, b) Konsep-konsep dan dan metode disiplin keilmuan, teknologi, atau seni yang relevan yang secara konseptual menaungi atau koheren dengan program satuan pendidikan, mata pelajaran, dan kelompok mata pelajaran yang dilampau.

Keempat kompetensi di atas secara holistik dan integratif dalam kinerja guru. oleh karena itu, secara utuh kompetensi guru meliputi: a). Pengenalan peserta didik secara mendalam, b). Penguasaan bidang studi baik disiplin ilmu (disciplinary content) maupun bahan ajar dalam kurikulum sekolah (pedagogical content) c). Penyelenggaraan pembelajaran mendidik yang meliputi perencanaan dan pelaksanaan pembelajaran, evaluasi proses, hasil belajar, serta tindak lanjut untuk perbaikan dan pengayaan. d). Pengembangan kepribadian dan profesionalitas secara berkelanjutan.

Lebih lanjut, dalam menjalankan kewenangan profesionalnya, guru dituntut memiliki berbagai kecakapan (competencies) psikologi yang meliputi: Kompetensi kognitif (kecakapan ranah cipta). Kompetensi kognitif guru mengandung bermacam-macam pengetahuan baik yang bersifat deklaratif maupun yang bersifat prosedural. Kompetensi afektif (kecakapan ranah rasa). Kompetensi ranah afektif guru bersifat tertutup dan abstrak, sehingga amat sukar untuk diidentifikasi, yang menjadi objek penelitian dan pembahasan psiokologi pendidikan adalah sikap dan perasaan diri yang berkaitan dengan profesi keguruan. Kompetensi psikomotor (kecakapan ranah karsa). Kompetensi ini meliputi segala keterampilan atau kecakapan yang bersifat jasmaniah yang pelaksanaannya berhubungan dengan tugasnya selaku pengajar.

Winarno Surakhmad (1979) dalam hasil penelitiannya terhadap siswa mengenai pendapat mereka tentang guru yang baik, sejumlah besar kelompok pelajar memberikan reaksi bahwa berdasarkan pengalaman mereka tentang guru yang paling mereka sukai adalah sebagai berikut: Bersikap ramah dan memahami siswa, adil dan tidak memihak, bersikap tegas, cerdas dan memiliki minat yang luas, memiliki rasa humor, memperlihatkan tingkah laku dan berpenampilan menarik. 
Di sekolah, kompeten personal akan menentukan simpatik tidaknya, akrab tidaknya guru dalam pandangan anak didik. Kerawanan hubungan guru dengan anak didik sangat ditentukan sejauh mana tingkat kualitas kompetensi personal yang dimiliki oleh guru. Sering guru tak diacuhkan oleh anak didik, disebabkan guru sendiri mengambil jarak dengan anak didik. Cukup banyak anak didik yang tak mengenal gurunya dengan baik disebabkan guru sangat jarang duduk bersama-sama dengan anak didiknya di luar kelas pada waktu luang untuk membicarakan apa saja yang berhubungan dengan masalah pelajaran dan kesulitan yang dialami para siswa. Penampilan guru dari ujung rambut sampai ujung kaki tak pernah lepas dari pengamatan anak didik. Pembicaraan guru, perilaku guru, sikap guru dalam menilai sesuatu, kemampuan guru dalam memecahkan masalah, kedisiplinan guru, kejujuran guru, dan bahkan cara guru berpakaian sekalipun tak pernah alpa dari penilaian anak didik. Semua itu disadari atau tidak oleh guru akan menjadi contoh bagi anak didik.

Padatnya aktifitas sekolah dan banyaknya kegiatan di sekolah fulldays seperti SMP Al-Aqsha membuat para siswa hanya memiliki waktu dan belajar yang sedikit dibandingkan dengan siswa yang tidak sekolah di SMP Plus Al-Aqsha. Para siswa di Al-aqsha memiliki beban belajar dan ujian yang cukup padat dan tinggi. Dengan adanya kegiatan yang begitu padat akan kah memberikan dampak pada motivasi belajar pada siswa. Siwa yang tampaknya tidak bermotivasi, mungkin pada kenyataannya cukup bermotivasi tapi tidak dalam hal-hal yang diharapkan pengajar.

"Motivasi adalah bagaimana tingkah laku di mulai, di beri energi, dipertahankan, diarahujiankan, dihentikan dan reaksi subjektif yang muncul dalam diri individu ketika peristiwa ini berlangsung (Jones, 1955 dalam teers \& Porters, 1991) “

Motivasi belajar pada setiap orang, satu dengan yang lainnya, bisa jadi tidak sama. Biasanya, hal itu bergantung dari apa yang diinginkan orang yang bersangkutan. Motivasi berpangkal dari kata motif yang dapat diartikan sebagain daya penggerak yang ada di dalam diri seseorang untuk melakukan aktifitas aktifitas tertentu demi tercapainya suatu tujuan.

Dalam proses belajar ada banyak faktor yang berperan, baik dari individu itu sendiri maupun dari stimulus yang datang. Salah satu faktornya adalah motivasi. Beberapa ahil mengemukakan definisi sebagai berikut :

Menurut De Cecco dan Crawford (1977) motivasi belajar merupakan kekuatan dari dalam diri siswa yang dapat meningkatkan dan menurunkan kekuatan dan usaha siswa untuk bertingkah laku dalam belajar.

Brophy (dalam Woolfolk 1998) mengemukakan motivasi belajar siswa merupakan kecenderungan siswa untuk mengeksplorasi aktivitas dalam akademis menjadi lebih berarti dan bermakna serta berusaha untuk menarik keuntungan dari aktivitas tersebut.

Dapat dijelaskan juga bahwa dalam kaitannya dengan konsep belajar, motivasi belajar mengandung arti keseluruhan daya penggerak psikis di dalam diri siswa yang menimbulkan kegiatan belajar, menjamin kelangsungan kegiatan belajar dan memberikan arah pada kegiatan belajar itu demi mencapai suatu tujuan (Winkel, 2009).

Dengan demikian kuat lemahnya motivasi belajar seseorang turut mempengaruhi keberhasilan belajar. Karena itu, motivasi belajar perlu diusahakan, terutama yang berasal dari dalam diri, yakni dengan cara senantiasa memikirkan masa depan yang penuh tantangan dan harus dihadapi untuk mencapai cita-cita.

Pada intinya bahwa motivasi merupakan kondisi psikologis yang mendorong seseorang untuk melakukan sesuatu. Dalam kegiatan belajar, motivasi dapat dikatakan sebagai keseluruhan daya penggerak didalam diri siswa yang menimbulkan, menjamin kelangsungan dan memberikan arah kegiatan belajar, sehingga diharapkan tujuan dapat tercapai. Dalam kegiatan belajar, motivasi sangat diperlukan, sebab seseorang yang tidak mempunyai motivasi belajar, tidak akan mungkin melakukan aktifitas belajar.

SMP plus Al-Aqsha yang berlokasi di jatinangor Sumedang merupakan sekolah yang menerapkan sistem boarding school. Yayasan Al-Aqsha membawahi dua lembaga pendidikan, yaitu SMP Plus Al-Aqsha dan KMMI (kulliyatul al-Mualimin wa al-Muallimat alIslamiyah). Secara operasional kedua lembaga di atas tidak dapat dipisahkan satu sama lain, karena keduanya dipadukan dalam sebuah wadah pendidikan yang disebut dengan SMP Plus Pondok Modern Al-Aqsha yang kemudian dikenal sebagai SMP Plus Al-Aqsha. Al-Aqsha memiliki dua kurikulum sekolah, pertama kurikulum Departemen Pendidikan Nasional, ke- 
dua kurikulum Pesantren. Pada kurikulum Departemen Pendidikan Nasional yang digunakan sebagai kurikulum formal SMP Plus Al-Aqsha, sedangkan untuk kurikulum Pondok Modern Gontor dan kurikulum salafi digunakan sebagai kurikulum plus atau pesantren. Perpaduan kurikulum tersebut diharapkan menjadi ciri khas dari SMP Plus Al-Aqsha yang didedikasikan untuk mencetak para santri/siswa siswi agar memiliki kompetensi baik di bidang pengetahuan umum maupun di bidang pengetahuan agama. Sistem pendidikan di SMP Plus Al-Aqsha adalah sistem pendidikan yang berbasis pondok pesantren, dikatakan demikian karena siswa SMP Plus Al-Aqsha diwajibkan untuk tinggal atau diasramakan. Adanya perpaduan kurikulum yang diberikan sekolah, secara tidak langsung mengharuskan para siswanya untuk mengikuti semua pembelajaran yang diberikan.

Dari kegiatan operasional Pondok Pesantren Al-Aqsha yang terdiri dari dua garis besar tersebut, yaitu yang berbasis Nasional dan Gontor maka diharapkan para staf pengajar/pendidik dituntut untuk lebih mengetahui dalam kegiatan oprasional SMP Plus AlAqsha. Pengajar/pendidik harus berkompeten dalam mengelola tata cara pembelajaran yang akan diberikan kepada para siswa/siswinya, sehingga siswa/siswi yang menerima pembelajaran dan menjadi termotivasi dalam menerima pembelajaran dari pengajar. Dalam hal ini, kompetensi guru diduga menjadi kunci utama dari kegiatan operasional SMP Plus AlAqsha, karena bagaimana mungkin siswa akan termotivasi dalam kegiatan belajarnya jika para pendidiknya tidak berkompeten.

Di SMP Plus Al-Aqsha mempunyai kegiatan belajar yang berbeda dengan SMP-SMP lainnya. Kompetensi yang harus dimiliki oleh pengajar/pendidik adalah bagaimana ia bersikap dihadapan para siswa/siswinya, sehingga sikap baik yang diperlihatkan oleh para pengajar/pendidik diikuti oleh para siswa/siswinya. Sehingga diwaktu yang akan datang para siswa/siswi mempunyai akhlakul karimah yang dicontohkan oleh Rosul-Nya dan dalam keberhasilan proses kegiatan belajar mengajar di sekolah, seorang pengajar harus memiliki kompetensi sesuai dengan kemampuan yang mereka miliki.

Sebagai seorang pengajar, guru merupakan penggerak kegiatan belajar para siswanya. Oleh karena itu, seorang guru dituntut untuk memiliki kemampuan-kemampuan dalam hal merencanakan suatu proses pembelajaran di sekolah maupun di kelas dan setiap guru harus menguasai dan terampil dalam melaksanakan kegiatan belajar mengajar. Seperti halnya di SMP Plus Al-Aqsha, seorang guru dituntut untuk memiliki suatu kompetensi pembelajaran yang baik, karena tinggi rendahnya motivasi belajar para siswa diduga berkaitan dengan kemampuan guru dalam memberikan pengajaran di kelas dan kompetensi guru. Namun demikian, meskipun pihak sekolah telah memberikan kesempatan kepada para guru untuk mengikuti berbagai pelatihan agar dapat meningkatkan kualitas pembelajarannya pada saat di kelas, pihak sekolah masih mengeluhkan motivasi belajar siswanya yang rendah. Oleh karena itu perlu diteliti lebih jauh mengenai keterkaitan kompetensi guru dan motivasi belajar para siswa di sekolah.

Dalam menjalankan tugasnya menjadi pendidik, seorang guru dituntut untuk mempunyai kompetensi-kompetensi yang berhubungan dengan perannya sebagai pengajar. Kompetensi adalah seperangkat pengetahuan keterampilan, dan prilaku yang harus dimiliki, dihayati dan dikuasai oleh guru dalam melaksanakan tugas keprofesionalan (Martinis Yamin, 2006). Kompetensi yang harus dimiliki oleh seorang guru menurut Undang-Undang No 14 tahun 2005 yakni: 1). Kompetensi Pedagogik, yaitu kemampuan mengelola pembelajaran peserta didik. 2). Kompetensi Kepribadian, yaitu kemampuan kepribadian yang mantap, berakhlak mulia, arif dan berwibawa, serta menjadi teladan bagi peserta didik. 3). Kompetensi Profesional, yaitu kemampuan penguasaan materi pelajaran secara luas dan mendalam. 4. Kompetensi Sosial, yaitu menyesuaikan diri dengan tuntutan lingkungan sekitar, pandai bergaul dan memahami siswa.

Sebagai seorang pengajar, guru merupakan penggerak kegiatan belajar para siswanya. Oleh karena itu, guru dituntut untuk memiliki kemampuan-kemampuan dalam hal merencanakan suatu proses pembelajaran di kelas. Kompetensi mengajar guru merupakan kemampuan yang dimiliki guru dalam kaitanya dengan pelaksanaan kegiatan belajar mengajar di kelas. Hal itu diharapkan guru tersebut memberikan motivasi kepada para siswa siswinya, sehingga siswa siswi tersebut menjadikan guru sebagai contoh. 
Dalam kegiatan belajar megajar, apabila ada seorang siswa, misalnya melakukan aktivitas yang seharusnya dikerjakan, maka perlu diselidiki sebab-sebabnya. Sebab-sebab itu biasanya bermacam-macam, mungkin ia tidak senang, mungkin sakit, ada problem pribadi, kurang motivasi, atau gurunya tidak dapat menyampaikan materinya dengan baik. Hal ini berarti pada diri siswa tidak terjadi perubahan energi, tidak terangsang afeksinya untuk melakukan sesuatu, karena tidak memiliki tujuan atau kebutuhan belajar.

Bagi seorang siswa, guru yang memiliki kepribadian mudah bergaul, supel, dapat mengerti perasaan siswa yang sedang mengalami kesulitan, dan memiliki rasa penghargaan yang tinggi terhadap mereka dapat dijadikan sebagai orang tua kedua bagi siswa. Kondisi ini mendorong siswa untuk menaruh kepercayaan yang tinggi kepada guru agar dapat membantu menghadapi kesulitan-kesulitan dalam proses belajar dan pergaulan di lingkungan sekolah. Sehingga akhirnya guru-guru yang memiliki kepribadian demikian dapat menjadi salah satu fa-tor yang mendorong siswa untuk belajar lebih semangat, lebih baik, dan lebih bertanggung jawab.

Demikian halnya guru yang mampu menjelaskan materi dengan baik, memiliki persiapan yang cukup, menguasai seluruh materi, dan menguasai isu-isu terbaru yang berkaitan dengan materi pelajaran, mampu menyusun materi secara runut. Kemampuan yang dimiliki guru tersebut membuat siswa menaruh rasa kagum, menaruh rasa hormat, mudah mencerna materi, tidak akan merasa bosan dalam belajar, dan semangat mengikuti proses belajar. Pada akhirnya guru tidak perlu harus repotrepot selalu memberi dorongan dan mengingatkan siswa untuk selalu belajar dengan baik karena mereka sudah terbangkitkan motivasi belajarnya dengan mengikuti proses pembelajaran yang menyenangkan.

Motivasi belajar siswa dapat datang dari dalam siswa ataupun dari luar diri siswa itu. Motivasi yang datang dari luar diri siswa tersebut salah satunya berasar dari staf pengajar yaitu guru itu sendiri. Hal ini secara tidak langsung mengaharuskan guru memiliki suatu kompetensi di depan siswa-siswinya.

Dalam kegiatan belajar, motif dapat dikatakan sebagai keseluruhan daya penggerak didalam diri siswa yang menimbulkan, menjamin keberlangsungan dan memberikan arah kegiatan belajar, sehingga diharapkan tujuan dapat dicapai. Motivasi sangat diperlukan dalam kegiatan belajar, sebab sesuatu yang tidak mempunyai motivasi dalam belajar, tidak akan mungkin melakukan aktivitas belajar.

Individu dalam bertingkah laku senantiasa dipengaruhi oleh motivasinya yang akan memberikan dorongan atau arahan tingkah laku yang dikeluarkannya. Motivasi akan memberikan alasan mengapa individu meningkatkan atau menurunkan tingkah laku tertentu. De Cecco dan Crawford (1977) menjelaskan bahwa motivasi merupakan sumber kekuatan siswa dalam belajar. Konsep motivasi belajar ini akan menjelaskan mengenai seberapa besar tingkat atau level dari aktifitas individu, yaitu mengenai usahanya dalam belajar dengan kata lain seberapa tinggi atau rendahnya motivasi belajar yang ditunjukkan oleh seseorang akan terlihat dari bagaimana usaha yang ditunjukkannya. Seberapa besar usaha dan energi yang ditunjukkan siswa dalam tingkah laku belajarnya merupakan salah satu faktor yang menentukan hasil belajar yang diperolehnya.

Faktor-faktor pembentuk dalam motivasi belajar (De Cecco dan Crawford, 1977) : 1). adalah Arousal, merupakan tingkat kesiapsiagaan individu untuk melakukan suatu aktivitas tertentu, seorang individu yang memiliki tingkat arousal tertentu akan memperlihatkan usaha-usaha yang menunjukkan telah terbangkitnya individu tersebut. 2). Expectancy atau harapan adalah beliefe yang sifatnya sementara, dimana suatu aktivitas tertentu akan diikuti oleh suatu hasil tertentu. Valensi berkaitan erat dengan konsep expectancy ini. Tenaga atau semangat yang timbul untuk melakukan suatu aktivitas merupakan hasil dari harapan dengan valensi. 3). Incentive, merupakan obyek tujuan yang nyata, yang dihubungkan dengan stimulus respon tertentu. Adanya incentive bertujuan agar siswa terus meningkatkan atau mempertahankan usaha yang dilakukan untuk meraih prestasi selanjutnya. 4). Punishment, adanya sesuatu hal yang menjadi hukuman dapat mencegah munculnya sesuatu yang tidak diinginkan.

\section{METODE PENELITIAN}

Penelitian ini dilakukan dengan menggunakan desain penelitian korelasional. Variabel yang akan diteliti adalah kompetensi guru dan motivasi belajar. Secara konseptual, yang 
dimaksud kompetensi guru dalam penelitian ini mengacu kepada pendapat Barlow (1985 dalam Muhibbinsyah, 2010: 229) yakni merupakan kemampuan seorang guru dalam melaksanakan kewajiban-kewajibannya secara bertanggungjawab dan layak. Sedangkan motivasi belajar dalam penelitian ini mengacu pada pendapat yang di utarakan oleh Winkel (2009) mengandung arti keseluruhan daya penggerak psikis di dalam diri siswa yang menimbulkan kegiatan belajar, menjamin kelangsungan kegiatan belajar dan memberikan arah pada kegiatan belajar itu demi mencapai suatu tujuan. Siswa yang memiliki motivasi belajar akan memiliki kecenderungan untuk menentukan aktivitas akademik yang bermakna, berguna dan dapat bermanfaat bagi umum.

Pada penelitian ini subjek yang akan diteliti adalah seluruh siswa kelas IX di SMP Plus Al-Aqsha yang berjumlah 130 orang, yang secara otomatis akan menjadi populasi target. Artinya bahwa semua subjek yang ada dalam populasi akan menjadi subjek penelitian.

Instrumen yang digunakan untuk menjaring data mengenai kompetensi guru disusun berdasarkan konsep Barlow serta mengacu pada Undang-Undang No 14 tahun 2005, sedangkan instrumen yang menjaring data mengenai motivasi belajar disusun berdasarkan konsep yang di utarakan oleh W.S Winkel (2009).

Uji statistik yang digunakan untuk menguji hubungan antara kedua variabel dalam penelitian ini adalah dengan menggunakan rumus Rank Spearman, karena data yang diperoleh dari alat ukur berskala ordinal. Prosedur penggunaan uji Rank spearman dilakukan dengan bantuan software SPSS v.19.

\section{HASIL DAN PEMBAHASAN}

\section{Hasil}

Berdasarkan hasil perhitungan yang diperoleh dapat diketahui bahwa nilai probabilitas sebesar 0,001 lebih kecil dari $\alpha=0,05$. Hal tersebut memiliki arti bahwa $\mathrm{H}_{0}$ dalam penelitian ini ditolak, artinya terdapat hubungan positif antara kompetensi guru dengan motivasi belajar siswa kelas 3 SMP Plus Al-Aqsha. Data lain yang diperoleh dari tabel tersebut adalah besarnya koefisien korelasi antara kompetensi guru dan motivasi belajar adalah sebesar 0,286. Indeks korelasi sebesar 0,286 tersebut memiliki arti tingkat korelasi rendah.
Berdasarkan hasil analisis deskriptif, diketahui bahwa dari 50\% siswa yang menganggap bahwa kompetensi guru adalah rendah, sebanyak 29,3\% (41 orang) siswa menunjukkan motivasi belajar yang rendah dan 20,7\% (29 orang) lainnya menunjukkan motivasi belajar yang tinggi. Hal tersebut memiliki arti, jumlah siswa yang menganggap kompetensi guru rendah dan memiliki motivasi belajar yang rendah lebih banyak bila dibanding dengan jumlah siswa yang memiliki motivasi belajar yang tinggi.

Selanjutnya, dari 50\% siswa yang menganggap bahwa kompetensi guru adalah tinggi, sebanyak 30\% (42 orang) siswa menunjukkan motivasi belajar yang tinggi dan $20 \%$ (28 orang) lainnya menunjukkan motivasi belajar yang rendah. Hal tersebut memiliki arti, jumlah siswa yang menganggap kompetensi guru tinggi dan memiliki motivasi belajar yang tinggi lebih banyak bila dibanding dengan jumlah siswa yang memiliki motivasi belajar yang rendah.

\section{Pembahasan}

Berdasarkan hasil penelitian diketahui bahwa terdapat hubungan positif antara kecerdasan kompetensi guru dengan motivasi belajar pada siswa kelas 3 SMP Plus Al-Aqsha meskipun dengan tingkat korelasi rendah. Data tersebut ditunjang oleh hasil analisis deskriptif diketahui bahwa sebagian besar siswa yang menganggap bahwa guru memiliki kompetensi yang rendah, menunjukkan motivasi belajar yang rendah pula. Demikian pula sebaliknya, sebagian besar siswa yang menganggap bahwa guru memiliki kompetensi yang tinggi, menunjukkan motivasi belajar yang tinggi pula.

Hasil penelitian ini menunjukkan bahwa tingkat kompetensi yang ditunjukkan oleh seorang guru dapat menjadi motivasi eksternal bagi siswanya. Hasil tersebut mendukung pernyataan Gage \& Berliner (1979) yang menyatakan bahwa motivasi belajar ekstrinsik adalah aktivitas belajar yang dimulai dan diteruskan berdasarkan kebutuhan dan dorongan yang tidak secara mutlak berkaitan dengan aktivitas belajar itu sendiri. Motivasi ekstristik dapat juga diartikan sebagai motivasi yang disebabkan oleh faktor-faktor dari luar situasi belajar seperti nilai, ijasah, hadiah, medali, tingkatan, persaingan dan sebagainya. 
Gage \& Berliner (1979) menjelaskan bahwa dalam bidang pendidikan, motivasi belajar merupakan suatu konsep yang berkaitan dengan faktor-faktor lain yang juga berpengaruh dalam memberikan dorongan dan arah pada tingkah laku belajar. Salah satu hal yang menjadi konsep eksternal adalah kompetensi yang ditampilkan oleh guru.

Sebagai seorang pengajar, guru merupakan penggerak kegiatan belajar para siswanya. Oleh karena itu, guru dituntut untuk memiliki kemampuan-kemampuan dalam hal merencanakan suatu proses pembelajaran di kelas. Kompetensi mengajar guru merupakan kemampuan yang dimiliki guru dalam kaitanya dengan pelaksanaan kegiatan belajar mengajar di kelas. Hal itu diharapkan guru tersebut memberikan motivasi kepada para siswa siswinya, sehingga siswa siswi tersebut menjadikan guru sebagai contoh.

Kompetensi utama yang harus dimiliki guru agar pembelajaran yang dilakukan efektif dan dinamis adalah kompetensi pedagogis. Guru harus belajar secara maksimal untuk menguasai kompetensi pedagogis ini secara teori dan praktik. Selain itu seorang guru dinilai tidak hanya dari aspek keilmuan saja, tapi juga dari aspek kepribadian yang ditampilkannya. Kepribadian menunjuk pada organisasi sikap-sikap seseorang untuk berbuat, mengetahui, berpikir dan merasakan secara khusus apabila dia berhubungan dengan orang lain atau menanggapi suatu keadaan.

Sikap dan perilaku guru menjadi cermin masyarakat. maka, dalam kehidupan sehari-hari, guru harus mempunyai kompetensi sosial. Guru tidak sekedar manusia biasa, tapi sosok manusia yang mempunyai idealisme tinggi dalam melakukan perubahan di tengah masyarakat kea rah yang lebih baik dan lebih dinamis. Selain itu, seorang guru juga dituntut untuk memiliki kemampuan dalam menguasai pengetahuan bidang ilmu teknologi dan seni.

Terdapat hal menarik dari data deskriptif yang dijelaskan sebelumnya, yaitu terdapat sebagian siswa yang menganggap bahwa guru memiliki kompetensi rendah namun menunjukkan motivasi belajar yang tinggi. Demikian pula sebaliknya, sebagian siswa yang menganggap bahwa guru memiliki kompetensi tinggi namun menunjukkan motivasi belajar yang rendah.

Hal tersebut dapat terjadi antara lain karena adanya motivasi instrinsik dalam diri sis- wa. Menurut Winkel (1996) motif adalah daya penggerak dialami diri seseorang untuk melakukan aktivitas-aktivitas tertentu demi mencapai tujuan tertentu. Motif merupakan suatu kondisi internal atau disposisi internal (kesiapsiagaan). Morgan (1986) mendefinisikan motivasi sebagai berikut: Motivation refers to the driving and pulling forces which result in persistent behaviour directed toward particular goal. " Motivasi merujuk pada kekuatan yang mengarahkan dan mendorong perbuatan (tingkah laku) yang tepat sesuai dengan tujuan yang telah ditentukan ". Sedangkan Mc. Donald (Sardiman 2000:71) mengatakan bahwa motivasi adalah perubahan energi dalam diri seseorang yang ditandai dengan munculnya feeling dan didahului dengan tanggapan terhadap adanya tujuan.

Menurut Gage \& Berliner (1979) motivasi instrinsik adalah kegiatan belajar yang dimulai dan diteruskan berdasarkan penghayatan siswa dan dorongan yang secara mutlak berkaitan dengan aktifitas belajar. Dengan kata lain motivasi instrinsik adalah motivasi yang tercakup didalam situasi belajar dan memenuhi kebutuhan serta tujuan siswa. Motivasi instrinsik adalah motivasi yang ada didalam diri individu dan berguna dalam situasi belajar yang fungsional, dalam hal ini pujian, hadiah atau sejenisnya tidak diperlukan karena tidak akan menyebabkan peserta didik bekerja atau belajar mendapat pujian atau hadiah tersebut.

Gage \& Berliner (1979) menjelaskan bahwa dalam bidang pendidikan, motivasi belajar berhubungan dengan minat. Dengan adanya minat, siswa akan dapat memusatkan perhatiannya kepada stimulus yang diminatinya. Siswa yang berminat terhadap suatu pelajaran akan memberikan perhatian yang tinggi terhadap pelajaran tersebut. Biasanya bila siswa telah berminat terhadap suatu pelajaran maka hasil yang dicapai akan lebih baik dan mereka akan merasa lebih puas terhadap hasil tersebut.

Dengan demikian dapat dikatakan bahwa siswa yang memiliki minat yang tinggi terhadap suatu pelajaran akan menunjukkan motivasi belajar yang tinggi, meskipun ia mendapatkan guru yang tidak kompeten. Demikian pula sebaliknya, siswa yang memiliki minat yang rendah pada satu mata pelajaran akan menunjukkan motivasi belajar yang rendah meskipun ia mendapatkan guru yang sangat kompeten. 
Motivasi intrinsik diperlukan disekolah sebab pembelajaran di sekolah tidak semuanya menarik minat, atau sesuai dengan kebutuhan siswa, jumlah orang-orang yang rajin dan bertanggung jawab tidak akan menanti instruksi dari orang di sekitarnya.

\section{SIMPULAN DAN SARAN}

\section{Simpulan}

Berdasarkan hasil analisis dan pembahasan tentang hubungan antara kompetensi guru dengan motivasi belajar pada siswa kelas 3 SMP Plus Al-Aqsha dapat ditarik simpulan sebagai berikut:

Persentase guru SMP Plus Al-Aqsha yang memiliki kompetensi tinggi sama banyak dengan persentase guru yang memiliki kompetensi rendah. Persentase siswa kelas 3 SMP Plus Al-Aqsha yang memiliki motivasi belajar yang tinggi, lebih banyak bila diban-dingkan dengan siswa yang memiliki motivasi belajar yang rendah. Terdapat hubungan positif dengan indeks korelasi sebesar 0,286, antara kompetensi guru dengan motivasi belajar pada siswa kelas 3 SMP Plus Al-Aqsha.

\section{Saran}

Berdasarkan hasil penelitian yang diperoleh, maka penulis mengajukan beberapa saran kepada pihak-pihak sebagai berikut:

Bagi pihak sekolah. Mengingat pentingnya peran kompetensi guru terhadap motivasi belajar siswa yang pada akhirnya berhubungan pula dengan prestasi belajarnya, maka pihak sekolah diharapkan menyediakan guru-guru yang kompeten. Dengan cara menyeleksi calon guru sesuai standard kompetensi yang dimiliki, memberikan pendidikan dan pelatihan pada pihak guru yang ada serta menjaga kontinuitas dari pendidikan serta pelatihan tersebut. Bagi pihak guru. Guru diharapkan mampu menjadi teladan dan sumber motivasi ekstrinsik bagi siswanya. Guru juga diharapkan mampu meningkatkan wawasan dalam mata pelajaran yang disampaikannya baik dalam teori maupun praktek, menampilkan diri sebagai pribadi yang menarik, mampu bersosialisasi dengan baik serta menunjukkan profesionalisme.

\section{DAFTAR PUSTAKA}

Arikunto, S. 2006. Prosedur Penelitian Suatu Pendekatan Praktik. Edisi revisi VI. Jakarta :RinekaCipta

Asmani, Jamal. M. 2009. 7 Kompetensi Guru Menyenangkan dan Professional. Jogjakarta : Power Books (Ihdina).

De Cecco, J.P and Crawford, W. 1977.The Psychology of Learning and Instruction 2 edition. New Delhi : Prentice- Hall.

Djamaran, Syaiful Bahri. 2002. Psikologi Belajar. Jakarta: Rineka Cipta.

Gage, N.L. and Berliner, D. C. 1964. Educational Psychology. Boston : Houghton Mifflin Company.

Muhammad Shagir. 2003. Skripsi. Bandung: Universitas Islam Negeri

Muhibbin, Syah. 2010. Psikologi Pendidikan dengan Pendekatan Baru edisi revisi. Cetakan ke-15. Bandung: PT. Remaja Rosdakarya.

Siagian, Sondang P. 2004. Teori Motivasi dan Aplikasinya. Jakarta: Rineka Cipta.

Sutikno, S. M. 2008. Belajar dan Pembelajaran, Bandung : Prospect

Slameto. 2003. Belajar dan Faktor-faktor yang Mempengaruhinya. Jakarta: Rineka Cipta

Undang-undang Republik Indonesia No 14 Tahun 2005 tentang Guru danDosen.

Undang-Undang Republik Indonesia No 20 Tahun 2003 tentang Pendidikan Nasional.

Yamin, Martinis. 2006. Sertifikasi Profesi Keguruan di Indonesia, di Lengkapi dengan UU. 14 tahun 2005 tentang guru dan Dosen. Jakarta: Gaung Persada Press. 